\title{
Biochemical Characterization and 16S rRNA Sequencing of Few Lipase-Producing Thermophilic Bacteria from Taptapani Hot Water Spring, Orissa, India
}

\author{
Satpal S. Bisht and Amrita K. Panda \\ Department of Biotechnology, Roland Institute of Pharmaceutical Sciences, Orissa, Berhampur 760010, India \\ Correspondence should be addressed to Satpal S. Bisht, sps.bisht@gmail.com \\ Received 13 January 2011; Accepted 15 February 2011 \\ Academic Editor: Triantafyllos Roukas
}

Copyright ( $) 2011$ S. S. Bisht and A. K. Panda. This is an open access article distributed under the Creative Commons Attribution License, which permits unrestricted use, distribution, and reproduction in any medium, provided the original work is properly cited.

Three lipase-producing thermophilic bacteria (AK-P1, AK-P2, and AK-P3) were isolated from the Taptapani hot water spring in Orissa, India. The crude extra cellular lipases from cell-free culture supernatant were reacted in an olive oil mixture, and their lipolytic activities were compared. Identification of the bacteria was carried out using biochemical tests, 16SrRNA sequencing and sequences submitted to NCBI GenBank. Strain AK-P3, exhibited the highest lipolytic activity of $5.5 \mathrm{U} / \mathrm{mL}$ was identified as Porphyrobacter sp. The lipolytic activities of strains AK-P1 and AK-P 2 were $4.5 \mathrm{U} / \mathrm{mL}$ and $3.5 \mathrm{U} / \mathrm{mL}$, respectively. Strains AK-P1 and AK-P2 were identified as Acinetobacter sp. and Brevibacillus spp. The GenBank accession numbers of the 16S rRNA gene sequences determined in this study for the strains AK-P1, AK-P2, and AK-P3 are HM359120, HM359119, and HM359118, respectively.

\section{Introduction}

Thermophiles are a group of microbes adapted to thrive in ecological niches such as deep-sea hydrothermal vents, hot springs, and solfataric fields. Thermophilic microorganisms are found to be potential and good alternative source of thermostable enzymes $[1,2]$. The investigation and application of thermostable enzymes from thermophilic microorganisms have received a lot of attention in industries ranging from food industry to waste management industries.

Thermophiles are of interest to enhance the thermostability of industrial enzymes. The modern concept of the nature of the thermostability of the enzymes from the thermophilic microorganisms can be reduced to two basic ideas. Firstly, the enhanced thermal stability of enzymes in thermophilic cells could be due to their molecular structure being different from that of their counter part mesophilic proteins. Secondly, the increased stability of the enzymes could be due to their supramolecular association with other components of the cell (lipids, polysaccharides, or proteins). In order to survive at high temperatures, thermophilic prokaryotes (Archaea and Eubacteria) adopt different strategies like GC-rich codons, the ratio of charged amino acids compared to uncharged amino acids, ionic interactions, amino acid preferences and their distribution, posttranslational modifications, and solute accumulation [3]. Most of the industrial microbial lipases derived from fungi and mesophilic bacteria [4]. Bacteria produce different classes of lipolytic enzyme, including carboxylesterases (EC 3.1.1.1), which hydrolyse small ester containing molecules at least partly soluble in water, true lipases (EC 3.1.1.3), which display maximal activity towards water insoluble long-chain triglycerides, and various types of phospholipase [5].

More than 50 lipases have been identified, purified, and characterized to date which originate from natural sources such as animals, plants, and microorganisms (native or genetically engineered). A large number of beneficial thermophiles which produced lipases with good thermal stabilities have been found in diverse habitats $[6,7]$. Their thermal stabilities particularly in the absence of sufficient amounts of water increase their popularity [8]. 


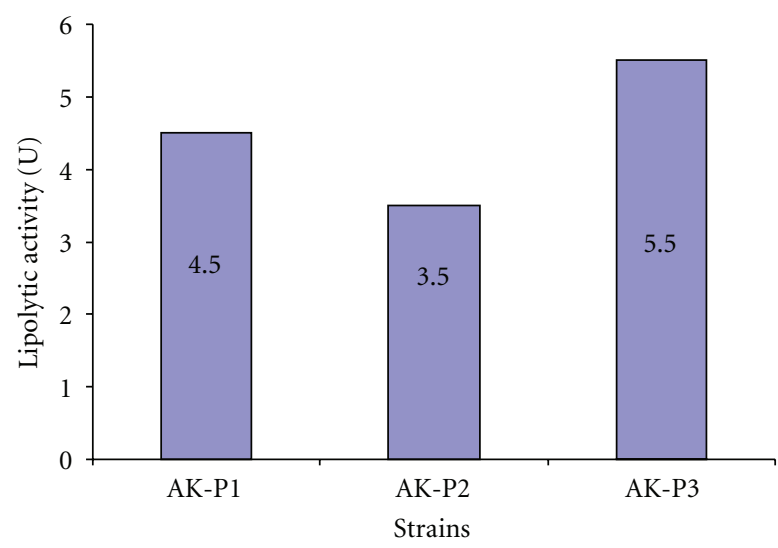

FIgURE 1: Lipolytic activities of lipase-producing bacteria isolated from Taptapani hot water spring.

TABLE 1: Colony morphology of isolates.

\begin{tabular}{lcccc}
\hline Strain & Colony size $(\mathrm{mm})$ & Colony morphology & Gram reaction & Cellular morphology \\
\hline AK-P1 & 1 & Circular, entire edge, Smooth surface & -ve & Coccoid \\
AK-P2 & 2 & Irregular and spreading Raised margin & +ve & Rods \\
AK-P3 & 1 & Circular, entire edge, Smooth surface, Orange pigmented & -ve & Ovoid to short rods \\
\hline
\end{tabular}

The enormous potential of microbial lipases arises from the facts that they are (1) quite stable and active in organic solvents, (2) do not require cofactors, (3) exhibit a high degree of enhantio- and regioselectivity, and (4) possess a wide range of substrate specificity for the conversion of various unnatural substrates $[9,10]$. Therefore screening and identification of thermostable lipolytic bacteria will act as a meaningful addition to the database on bacterial lipase research.

\section{Material and Methods}

2.1. Conventional Identification Tests. All isolates were initially evaluated by conventional tests, that is, Gram stain, growth, and morphometric characteristics on thermus agar ATCC 697 medium, growth at $42^{\circ} \mathrm{C}$, catalase, oxidase, motility, indole production, gelatin liquefaction, oxidative fermentative carbohydrate utilization, decarboxylation of lysine, and urease activity. Additional tests included phenylalanine deamination, nitrate reduction, citrate utilization, $\mathrm{H}_{2} \mathrm{~S}$ production, hydrolysis of starch, and growth in the presence of $6.5 \%$ sodium chloride.

2.2. Culture Maintenance. The cultures AK-P1, AK-P2, and AK-P3 isolated from Taptapani hot water spring $\left(19^{\circ} 30^{\prime} 0 \mathrm{~N}\right.$ lat and $84^{\circ} 24^{\prime} 0 \mathrm{E}$ long) of Ganjam District, Orissa, India were maintained on thermus agar and stored at $4^{\circ} \mathrm{C}$.

2.3. Screening for Lipase-Producing Bacteria. Screening of lipase producers was carried out using tributyrin agar plate according to Lawrence 1967. Each culture was streaked onto the tributyrin agar plate and incubated at $48^{\circ} \mathrm{C}$ for 2 days.
The lipase producing bacteria were identified by the presence of surrounding clear hydrolytic zones.

2.4. Lipolytic Assay of Lipase Producers. The identified bacterial lipase producers were cultivated in production medium $(50 \mathrm{~mL})$ in triplicate (one control and two replicates/sample). After incubation at $48^{\circ} \mathrm{C}$ for $36 \mathrm{~h}$ the cultures were centrifuged at $8000 \mathrm{rpm}$ at $4^{\circ} \mathrm{C}$ for $15 \mathrm{~min}$. The crude lipase solution was obtained by filtering through a millipore $0.22 \mu \mathrm{m}$ filter membrane and lipolytic activity was measured by universal titrimetric method $[11,12]$. Each reading was taken in triplicate and the activity was calculated as amount of enzyme required liberating one micromole equivalent fatty acid per $\mathrm{mL} / \mathrm{min}$.

2.5. DNA Preparation and PCR Amplification. Genomic DNA was extracted from the isolates using Chromous Genomic DNA isolation kit (RKT09). Each genomic DNA used as template was amplified by PCR with the aid of $16 \mathrm{SrDNA}$ primers (16S Forward Primer: $5^{\prime}$ AGAGTRTGATCMTYGCTWAC-3' 16S Reverse Primer: 5' CGYTAMCTTWTTACGRCT- $3^{\prime}$ ) with the programme consisted of denaturation at $94^{\circ} \mathrm{C}$ for $5 \mathrm{~min}$ and subsequent 35 cycles of denaturation at $94^{\circ} \mathrm{C}$ for $30 \mathrm{sec}$, annealing at $55^{\circ} \mathrm{C}$ for $30 \mathrm{sec}$, and extension at $72^{\circ} \mathrm{C}$ for $2 \mathrm{~min}$ followed by final extension at $72^{\circ} \mathrm{C}$ for $5 \mathrm{~min}$. The presence of PCR products was determined by electrophoresis of $10 \mu$ Lof the reaction product in a $1 \%$ agarose gel.

2.6. $16 S$ rRNA Sequencing and Data Analysis. Sequencing analysis was performed on a $1500 \mathrm{bp}$ PCR product. The sequence analysis was performed using the ABI 3130 genetic 


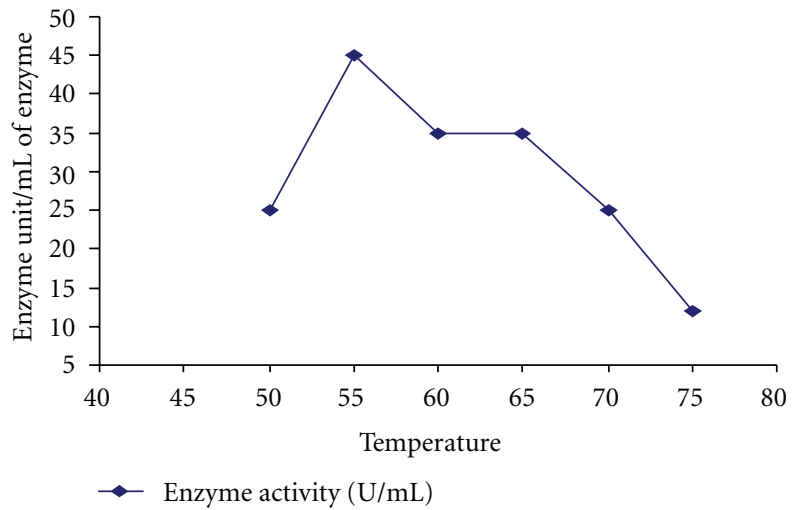

FIgURE 2: Thermal stability of crude lipase produced by AK-P3.

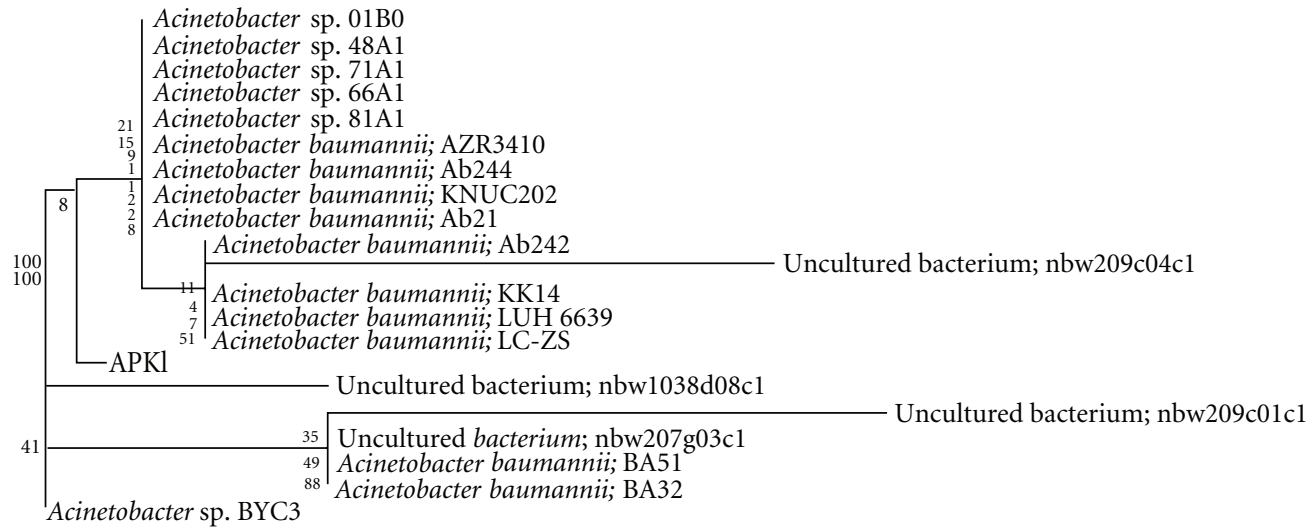

0.001

FIGURE 3: Phylogenetic position based on $16 \mathrm{~S}$ rRNA gene sequence analysis of strain AK-P1.

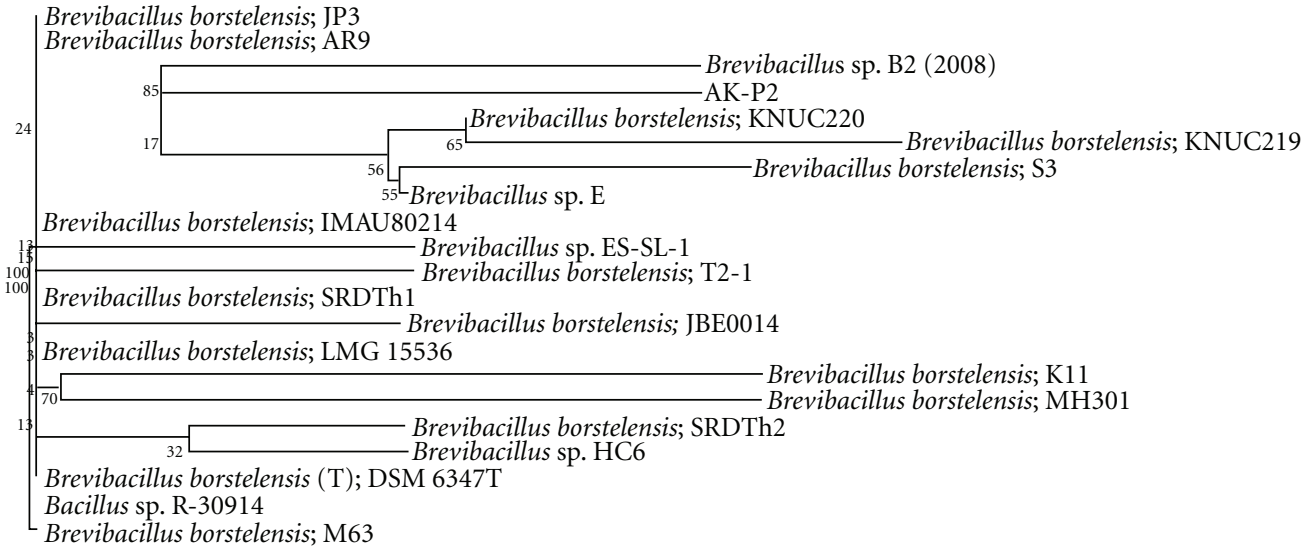

0.001

FIGURE 4: Phylogenetic position based on 16S rRNA gene sequence analysis of strain AK-P2. 

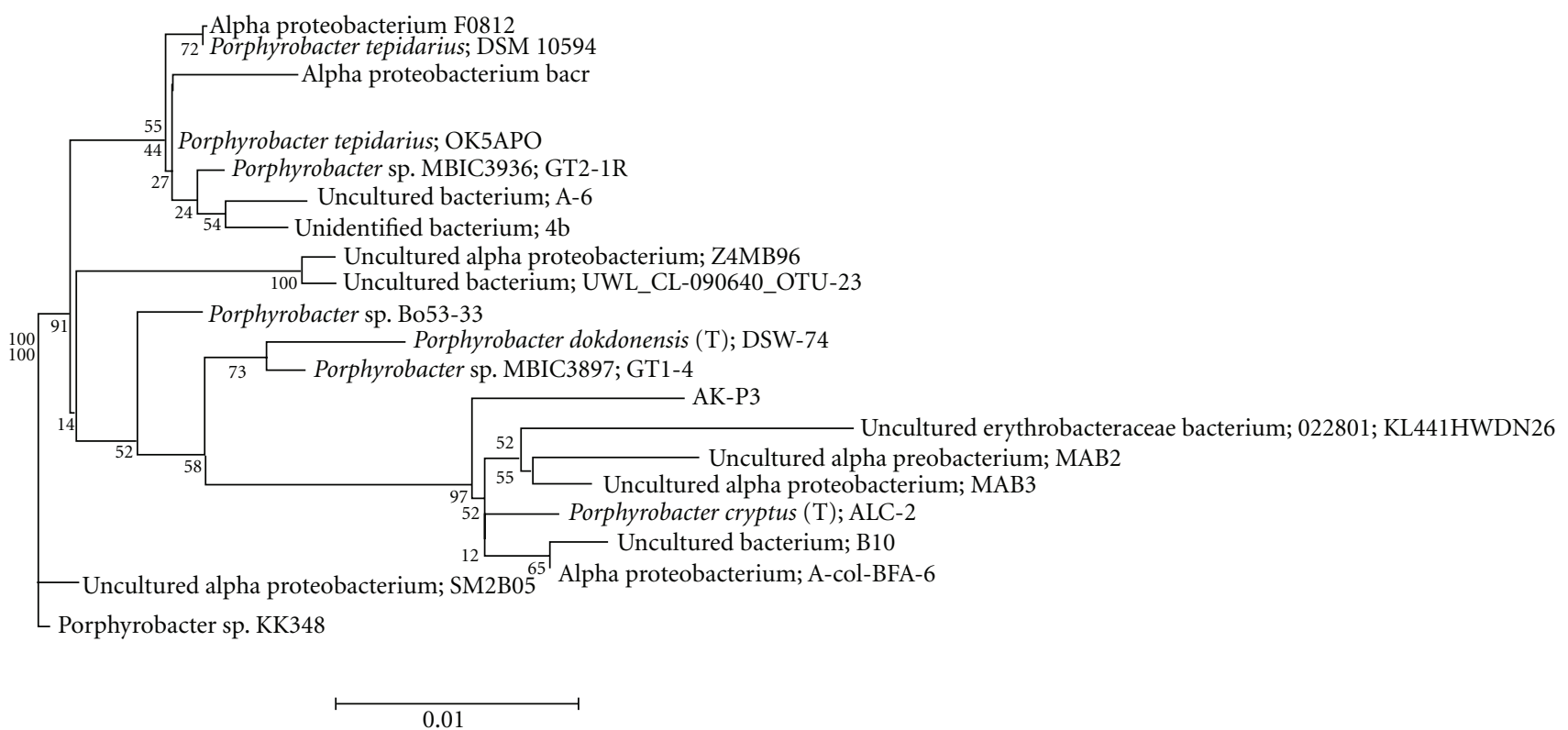

FIgURE 5: Phylogenetic position based on 16S rRNA gene sequence analysis of strain AK-P3.

analyzer and Big Dye Terminator version 3.1 cycle sequencing kit. The three 16SrRNA sequences were aligned and compared with other 16SrRNA genes in the GenBank by using the NCBI Basic Local alignment search tools BLAST $n$ program (http://www.ncbi.nlm.nih.gov/BLAST). A distance matrix was generated using the Jukes-cantor corrected distance model. The phylogenetic trees created using Weighbor (Weighted Neighbor Joining: A Likelihood-Based Approach to Distance-Based Phylogeny Reconstruction) with alphabet size 4 and length size 1000. The 16SrRNA gene sequences have been deposited to Genbank using BankIt submission tool and has been assigned with NCBI accession numbers.

\section{Results and Discussion}

3.1. Comparative Lipolytic Activity of Lipase Producers. Lipolytic activities of three lipase-producing bacteria are shown in Figure 1. All the three cultures showed good lipolytic activities. Strain AK-P3 exhibited the highest lipolytic activity of $5.5 \mathrm{U} / \mathrm{mL}$ followed by strains AK-P1 and AK-P2 with an activity of $4.5 \mathrm{U} / \mathrm{mL}$ and $3.5 \mathrm{U} / \mathrm{mL}$, respectively, (Figure 1).

3.2. Thermostability of Crude Lipase of AK-P3. The enzyme has shown very good stability up to $65^{\circ} \mathrm{C}$ for $20 \mathrm{~min}$. Further it decreased considerably at $70^{\circ} \mathrm{C}$ followed by a sharp decline in enzyme activity after $70^{\circ} \mathrm{C}$. The exposure of the enzyme at $75^{\circ} \mathrm{C}$ for 20 min decreases the enzyme activity to $26 \%$ of the total activity (Figure 2).

\subsection{Colony Morphology, Gram Reaction. See Tables 1 and 2.}

3.4. $16 S$ rRNA Sequence Analysis. More than $1400 \mathrm{bp}$ of the $16 \mathrm{~S}$ rRNA genes of strains AK-P1, AK-P2, and AK-P3 were sequenced. Analysis of the 16S rRNA sequences confirmed
TABLE 2: Results of biochemical tests.

\begin{tabular}{|c|c|c|c|}
\hline \multirow{2}{*}{ Biochemical tests } & \multicolumn{3}{|c|}{ Results } \\
\hline & AK-P1 & AK-P2 & AK-P3 \\
\hline \multicolumn{4}{|l|}{ Carbohydrate fermentation } \\
\hline Glucose & $+\mathrm{ve}$ & - ve & - ve \\
\hline Adonitol & - ve & - ve & +ve, weak \\
\hline Lactose & - ve & $-\mathrm{ve}$ & $-\mathrm{ve}$ \\
\hline Arabinose & - ve & - ve & +ve, weak \\
\hline Sorbitol & $-\mathrm{ve}$ & - ve & - ve \\
\hline Citrate utilization & - ve & - ve & - ve \\
\hline Indole & - ve & $-\mathrm{ve}$ & $+\mathrm{ve}$ \\
\hline Motility & - ve & - ve & $+\mathrm{ve}$ \\
\hline Nitrate reduction & $+\mathrm{ve}$ & + ve & $-\mathrm{ve}$ \\
\hline Lysine utilization & - ve & - ve & - ve \\
\hline Ornithine utilization & - ve & - ve & $-\mathrm{ve}$ \\
\hline Phenylalanine deamination & - ve & - ve & - ve \\
\hline Urease production & - ve & $-\mathrm{ve}$ & - ve \\
\hline $\mathrm{H}_{2} \mathrm{~S}$ production & $-\mathrm{ve}$ & - ve & $+\mathrm{ve}$ \\
\hline Catalase & $+\mathrm{ve}$ & + ve & +ve, weak \\
\hline Oxidase & $-\mathrm{ve}$ & - ve & $-\mathrm{ve}$ \\
\hline Methyl Red & - ve & $-\mathrm{ve}$ & - ve \\
\hline Voges-Proskauer & - ve & + ve & - ve \\
\hline Starch hydrolysis & - ve & + ve & $+\mathrm{ve}$ \\
\hline Gelatin liquefaction & - ve & $-\mathrm{ve}$ & - ve \\
\hline
\end{tabular}

+ Positive result; - Negative result.

the strain AK-P1 was most similar to Acinetobacter sp. 01B0 (Figure 3). The strain AK-P2 was found to be most similar to Brevibacillus sp. B2 (Figure 4) and the strain AK-P3 shares closest homology with Porphyrobacter cryptus (T) ALC-2 (Figure 5). 


\section{Acknowledgment}

The authors are thankful to administration and management of Roland Institute of Pharmaceutical Sciences, Berhampur, Orissa, India.

\section{References}

[1] T. D. Brock, Thermophilic Microorganisms and Life at High Temperatures, Springer, New York, NY, USA, 1978.

[2] T. D. Brock, "Life at high temperatures," Science, vol. 230, no. 4722, pp. 132-138, 1985.

[3] S. Trivedi, H. S. Gehlot, and S. R. Rao, "Protein thermostability in Archaea and Eubacteria," Genetics and Molecular Research, vol. 5, no. 4, pp. 816-827, 2006.

[4] R. Sharma, Y. Chisti, and U. C. Banerjee, "Production, purification, characterization, and applications of lipases," Biotechnology Advances, vol. 19, no. 8, pp. 627-662, 2001.

[5] J. L. Arpigny and K. E. Jaeger, "Bacterial lipolytic enzymes: classification and properties," Biochemical Journal, vol. 343, no. 1, pp. 177-183, 1999.

[6] Y. Wang, K. C. Srivastava, G. J. Shen, and H. Y. Wang, “Thermostable alkaline lipase from a newly isolated thermophilic Bacillus, strain A30-1 (ATCC 53841)," Journal of Fermentation and Bioengineering, vol. 79, no. 5, pp. 433-438, 1995.

[7] T. O. Akanbi, A. L. Kamaruzaman, F. Abu Bakar et al., "Highly thermostable extracellular lipase-producing Bacillus strain isolated from a Malaysian hotspring and identified using $16 \mathrm{~S}$ rRNA gene sequencing," International Food Research Journal, vol. 17, no. 1, pp. 45-53, 2010.

[8] N. Nawani, N. S. Dosanjh, and J. Kaur, "A novel thermostable lipase from a thermophilic Bacillus sp.: characterization and esterification studies," Biotechnology Letters, vol. 20, no. 10, pp. 997-1000, 1998.

[9] T. Nakatani, J. Hiratake, K. Yoshikawa, T. Nishioka, and J. Oda, "Chemical inactivation of lipase in organic solvent: a lipase from Pseudomonas aeruginosa TE3285 is more like a typical serine enzyme in an organic solvent than in aqueous media," Bioscience Biotechnology and Biochemistry, vol. 56, pp. 1118$1123,1992$.

[10] K. E. Jaeger and M. T. Reetz, "Microbial lipases form versatile tools for biotechnology," Trends in Biotechnology, vol. 16, no. 9, pp. 396-403, 1998.

[11] F. Cardenas, E. Alvarez, M. S. de Castro-Alvarez et al., "Screening and catalytic activity in organic synthesis of novel fungal and yeast lipases," Journal of Molecular Catalysis B, vol. 14, no. 4-6, pp. 111-123, 2001.

[12] T. Godfrey and S. West, "Introduction to industrial enzymology," in Industrial Enzymology, T. Godfrey and S. West, Eds., pp. 1-8, Stockton, New York, NY, USA, 2nd edition, 1996. 

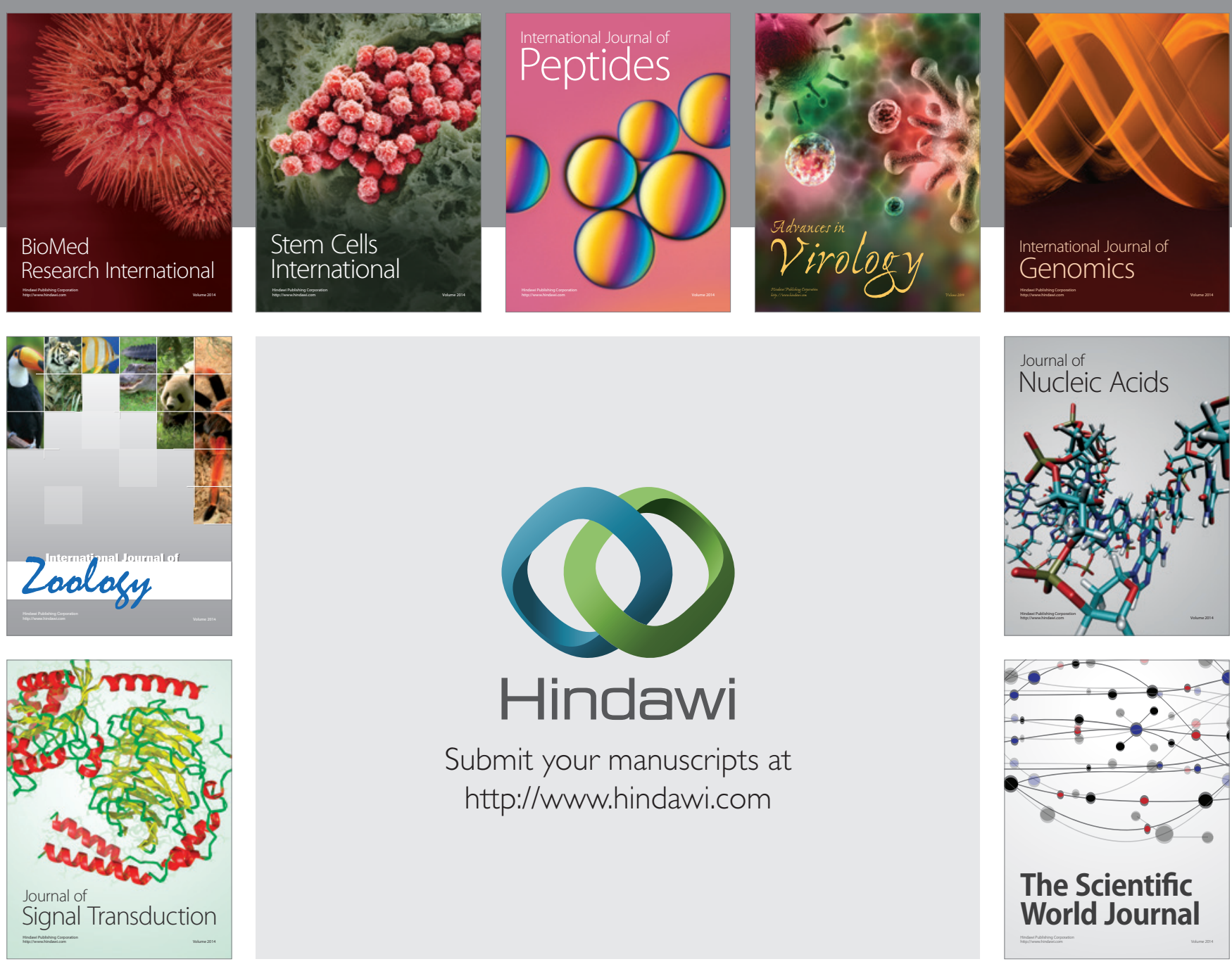

Submit your manuscripts at

http://www.hindawi.com
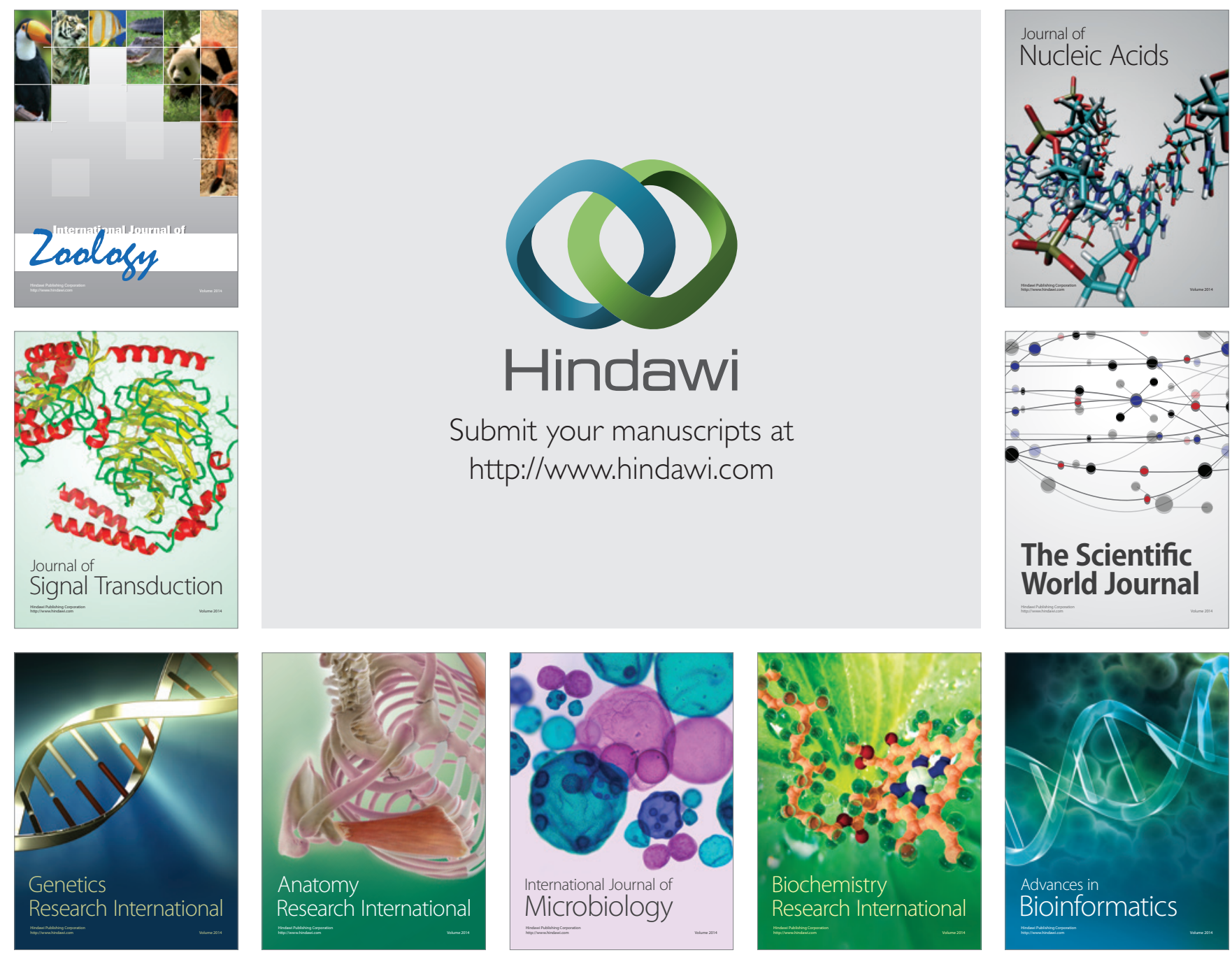

The Scientific World Journal
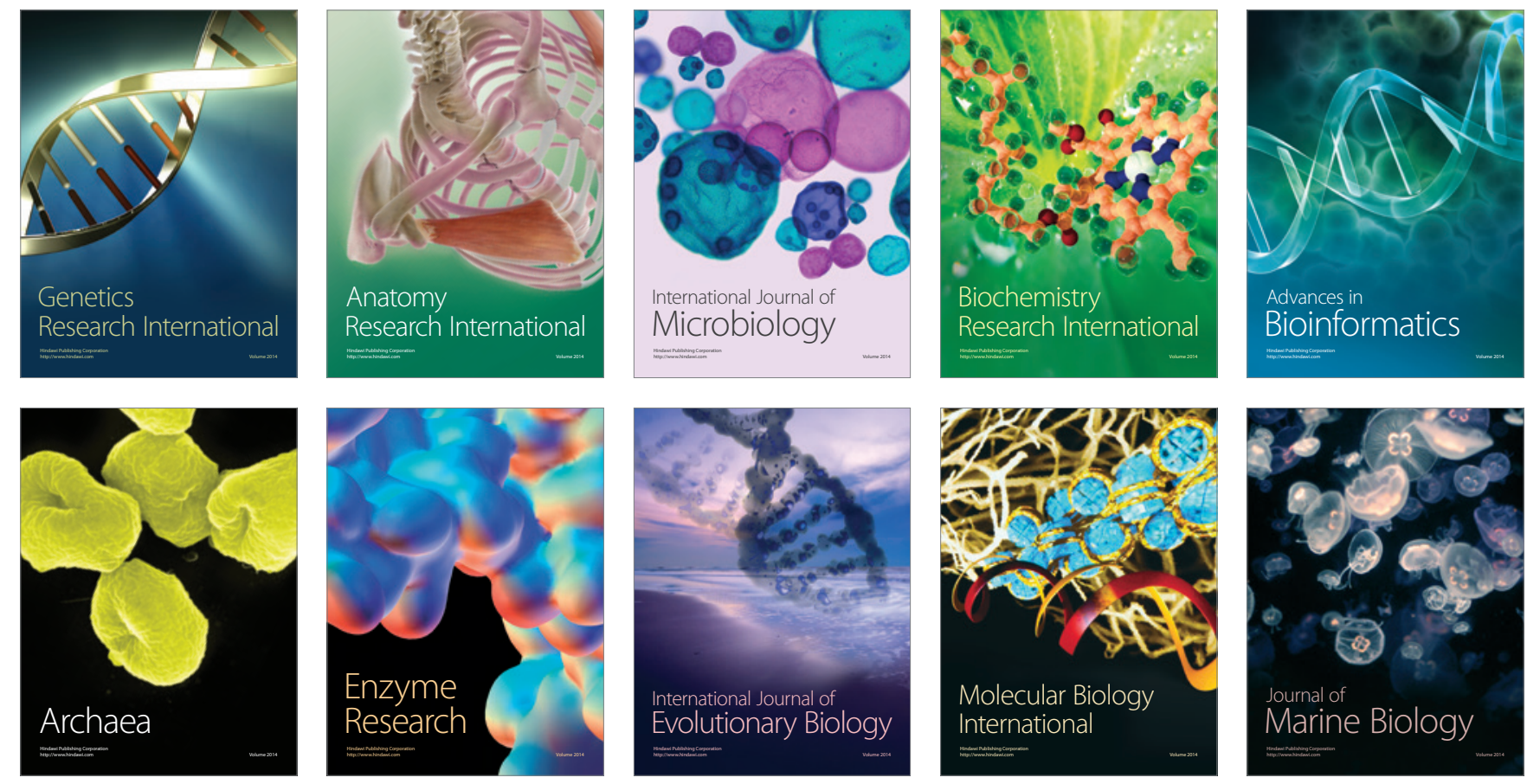